\title{
Nonelective Left-Sided Colon Cancer Resections are Associated with Worse Postoperative and Oncological Outcomes: A Propensity-Matched Study
}

\author{
Mircea Beurann, ${ }^{1,2}$, Ionut Negoi ${ }^{1,2}$, Mihaela Vartic ${ }^{3}$, Alexandru Runcanu², Cezar Ciubotaru², Adelina Cruceru², \\ Alina Prodan ${ }^{2}$
}

${ }^{1}$ Carol Davila University of Medicine and Pharmacy Bucharest, Romania

${ }^{2}$ Department of General Surgery, Emergency Hospital of Bucharest, Romania

${ }^{3}$ Department of Anesthesia and Intensive Care, Emergency Hospital of Bucharest, Romania

Corresponding author:

Mircea Beuran, MD, Ph.D., FACS

Professor of Surgery

Carol Davila University of Medicine

and Pharmacy Bucharest

General Surgery Department

Emergency Hospital of Bucharest

No 8 Floreasca Street, District 1

014461, Bucharest, Romania

E-mail: drbeuranmircea@yahoo.com

Received: 31.07 .2017

Accepted: 01.11.2017

\section{Rezumat}

Rezectiile non-elective pentru cancerul de colon stâng sunt asociate cu rezultate postoperatorii și oncologice nefavorabile: un studiu propensity-matched

Introducere: Pacienții cu o intervenție chirurgicală în regim de urgență au un risc considerabil mai ridicat de a dezvolta complicații postoperatorii şi prezintă o mortalitate mai mare comparativ cu cei operați electiv. Deşi contrazisă de unele studii, dovezile actuale susțin că pacienții cu intervenții colorectale în urgență prezintă o rată semnificativ mai mare a complicațiilor postopertorii şi rezultate oncologice nefavorabile.

Metodă: Am inclus în acest studiu toți pacienții cu cancer de colon internați în Spitalul Clinic de Urgență Bucureşti în perioada Ianuarie 2011 - Ianuarie 2016. Criteriile de selectie au fost: (1) tumora colonică; (2) localizare la nivelul colonului stâng; (3) adenocarcinom la examenul histopatologic. Criterii de excludere: (1) cancer rectal; (2) patologie benignă (ex. diverticulita).

Rezultate: Au fost incluşi 615 pacienți cu cancer de colon stâng. 275 (44.7\%) dintre pacienți s-au prezentat cu boală malignă complicată. Complicațiile au fost reprezentate de obstructie la 205 (33.3\%) pacienți (GO), hemoragie la $55(8.9 \%)$ pacienți $(\mathrm{GH})$ şi perforație la $15(2.4 \%)$ pacienți (GP). Rata de fistulă anastomotică a fost similară la cei din grupul cu obstrucție cu cei operați electiv $(6.2 \%$ versus $6.5 \%, \mathrm{P}>0.05)$, dar a fost semnificativ mai mare pentru pacienții cu hemoragie $(16 \%)(\mathrm{P}=0.046)$. Rata de complicații şi 
mortalitatea la 30 de zile au fost semnificativ mai mari la pacienții operați în regim urgență $(\mathrm{P}<0.05)$.

Concluzii: Prognosticul pe termen scurt şi cel pe termen lung a fost nefavorabil pentru pacienții operați non-electiv pentru cancer de colon stâng. Corelând prognosticul rezervat cu rata de incidență crescută a bolii complicate, putem reafirma impactul semnificativ al malignitații colonice complicate în populația generală.

Cuvinte cheie: cancer de colon, complicație, chirurgie de urgență

\section{Abstract}

Background: Emergency general surgery patients are at significant risk of postoperative complications and mortality compared with their elective counterparts. Although challenged by some studies, increasing evidence shows that emergency colectomy for cancer is associated with worse early postoperative and long-term outcomes.

Methods: We have included all patients with colon cancer admitted to the Emergency Hospital of Bucharest between January 2011 and January 2016. Selection criteria: (1) colon tumor; (2) left-sided localization of the tumor; (3) pathology exam revealing adenocarcinoma. Exclusion criteria: (1) rectal cancers; (2) benign pathology (e.g. diverticulitis).

Results: We included 615 patients with left-sided colon cancer. 275 (44.7\%) patients presented complicated disease. The complication was represented by obstruction in $205(33.3 \%)$ patients (OG), hemorrhage in $55(8.9 \%)$ patients (HG), and perforation in $15(2.4 \%)$ patients (PG). The anastomotic leakage rate was similar between obstructive and elective cases ( $6.2 \%$ versus $6.5 \%, \mathrm{P}>0.05)$, but was significantly higher for hemorrhagic patients $(16 \%)(\mathrm{P}=0.046)$. The 30-day complication rate and mortality were significantly higher in emergency patients $(\mathrm{P}<0.05)$.

Conclusions: We found significant worse short- and long-term outcomes for patients with nonelective left-sided colon cancer resections. Correlating the ominous prognosis with the high incidence of the complicated disease, we may emphasize the impact on de complicated colon cancer on the general population.

Key words: colon cancer, complicated disease, emergency surgery

\section{Introduction}

Emergency general surgery patients are at significant risk of postoperative complications and mortality compared with their elective counterparts $(1,2)$. Although challenged by some studies (3), increasing evidence shows that emergency colectomy for cancer is associated with worse early postoperative and long-term outcomes (4-6).

Analysis of colorectal cancer survival showed an increasing 30-day survival, from 86\% (time interval 1977 - 1982) to $90 \%$ (time interval 1995 - 1999) for colon cancer and from $90 \%$ to $94 \%$ for rectal cancer (7). Nevertheless, the emergency surgery for colon and rectal cancers was associated with a pooled 30-day mortality of $22.1 \%$, significantly higher than $6.2 \%$ for elective patients (7). On the other hand, the emergency presentation was associated with poorer overall survival even in node negative patients with curative intent surgery (5-year overall survival $66.8 \%$ versus $91.8 \%, \mathrm{P}<$ $0.001)(6)$.

The necessity for direct research and quality improvement audits was underlined by a national cohort study coming from the United Kingdom, which showed that outliers hospitals regarding mortality after elective and nonelective colorectal surgery do not correlate closely 
(8). Analysis of Nationwide Inpatients Sample from the United States revealed significant state-by-state variation in emergency colec- $^{-}$ tomies (9). After inclusion of 203050 patients, the authors found the highest proportion of emergent procedures in Nevada (53.6\%) and the lowest in Texas (22.8\%) (9). Besides the detrimental impact on patients' outcomes, the emergency surgery is also associated with incremental costs, with $\$ 8741.22 \quad(53 \%$ increase) in colon resections (10). Proposed measures to improve the disease specific survival in patients with emergency colon resections maybe a more extended lymph node assessment, better follow-up, and better utilization of adjuvant chemotherapy (11). Public healthcare policies, such as colorectal cancer screening, seems to decrease the rate of emergency resections and to save lives (12). Description of populational groups at high risk for developing complicated colorectal cancer, such as older, socially deprived and ethnic minority patients (12) could improve survival outcomes for colorectal cancer.

The implications of colon cancer diagnosis after the emergency presentation are underresearched, with a wide heterogeneity throughout the literature regarding the definition of emergency cases and patients' inclusion criteria (13).

The objective of this article is to evaluate the short-term perioperative morbidity and the long-term oncological outcomes of patients with nonelective left-sided colon cancer, comparing them with those of elective patients.

\section{Methods}

\section{Patients}

We have included all patients with colon cancer admitted to the Emergency Hospital of Bucharest between January 2011 and January 2016. Selection criteria: (1) colon tumor; (2) left-sided localization of the tumor; (3) pathology exam revealing adenocarcinoma. Exclusion criteria: (1) rectal cancers; (2) benign pathology (e.g. diverticulitis). We have defined as complication the diagnosis of an obstructive, hemorrhagic, or perforated tumor, without using a cutoff value for the time interval between admission and operating room.

\section{Variables}

We extracted the following data: patients' demographics, status on admission (emergency or not), TNM stage of the disease, pre-existing co-morbidities, overall survival, hospital stay, anastomotic leakage, postoperative complications according to Clavien-Dindo scale, surgical data (surgical approach, presence of loop ileostomy, on-table lavage, type of colon resection, type of anastomosis, duration of surgery), postoperative treatment, blood samples, pathology exam of the resection specimen. We have divided the patients into nonelective (complicated) and elective (un-complicated) groups.

\section{Primary Outcome}

The primary outcome of the present study was the overall survival, defined as the time interval between surgical procedure and death.

\section{Secondary Outcomes}

The secondary outcomes include the 30-day complication rate.

\section{Statistical Analysis}

We presented the continuous variable as mean and standard deviation and the categorical variables as number and percentages. We have used Chi-square tests, Independent Samples T-Test, One-Way ANOVA as statistical tests, where appropriate. For survival analysis, we used Kaplan-Meier analysis and Long Rank (Mantel-Cox) test. We performed propensity score matching, using as covariates the TNM stage and the age of patients. We used a match tolerance of 0.25. 270 matches were obtained. The incremental rejection percentage was 71.199.

For statistical analysis, we have used Statistical Package for Social Sciences (SPSS) version 20 and $R$ Statistical Software version 
3.4.1. To claim statistical significance, we used a $\mathrm{P}<0.05$.

\section{Results}

We included 615 patients with left-sided colon cancer. $275(44.7 \%)$ patients presented complicated disease (see Table 1). The complication was represented by obstruction in 205 (33.3\%) patients (OG), hemorrhage in $55(8.9 \%)$ patients (HG), and perforation in $15(2.4 \%)$ patients (PG). The mean age was $66.07 \pm 12.52$ years in complicated patients (CG) and $67.63 \pm 11.04$ in elective cases $(\mathrm{EG})(\mathrm{P}=0.102)$. There was no difference in sex distribution between the groups, male representing 120 (58.5\%), $30(54.5 \%), 10$ (66.7\%), and $190(55.9 \%)$ of cases in obstructing, hemorrhage, perforation, and elective groups (P Chi-square Tests $>0.05$ ). Patients with complicated disease presented more advanced TNM stages (see Table 2). The hospital stay was significantly longer for emergency cases (11.55 \pm 3.91 versus $7.5 \pm 2.05$ days, $\mathrm{P}<0.001)$. Emergency surgery was

Table 1. Characteristics of the included patients

\begin{tabular}{|c|c|c|c|}
\hline Variable & Group & $\begin{array}{l}\text { Data (number and percentages } \\
\text { or mean and standard deviation) }\end{array}$ & Statistical significance \\
\hline \multirow[t]{4}{*}{ Complication } & Obstruction & $205(33.3 \%)$ & \\
\hline & Hemorrhage & $55(8.9 \%)$ & \\
\hline & Perforation & $15(2.4 \%)$ & \\
\hline & Elective & $340(55.3 \%)$ & \\
\hline \multirow[t]{4}{*}{ Sex (Male) } & Obstruction & $120(58.5 \%)$ & \multirow[t]{4}{*}{ P Chi-square Tests $>0.05$} \\
\hline & Hemorrhage & $30(54.5 \%)$ & \\
\hline & Perforation & $10(66.7 \%)$ & \\
\hline & Elective & $190(55.9 \%)$ & \\
\hline \multirow[t]{4}{*}{ Age (years) } & Obstruction & $64.85 \pm 13.72$ & \multirow{4}{*}{$\begin{array}{l}\text { - P Post Hoc Tests Hemorrhage vs } \\
\text { Obstruction }=0.008 \\
\text { - P Post Hoc Tests Obstruction vs. } \\
\text { Elective }=0.043\end{array}$} \\
\hline & Hemorrhage & $70.54 \pm 6.57$ & \\
\hline & Perforation & $66.33 \pm 7.62$ & \\
\hline & Elective & $67.63 \pm 11.04$ & \\
\hline \multirow{4}{*}{$\begin{array}{l}\text { Hospital stay } \\
\text { (days) }\end{array}$} & Obstruction & $11.72 \pm 4.50$ & \multirow{4}{*}{$\begin{array}{l}\text { - P Post Hoc Tests Obstruction vs. } \\
\text { Elective }<0.001 \\
\text { - P Post Hoc Tests Hemorrhage vs. } \\
\text { Elective }<0.001 \\
\text { - P Post Hoc Tests Perforation vs. } \\
\text { Elective }<0.001\end{array}$} \\
\hline & Hemorrhage & $10.98 \pm 1.08$ & \\
\hline & Perforation & $11.47 \pm 1.18$ & \\
\hline & Elective & $7.5 \pm 2.03$ & \\
\hline \multirow{3}{*}{$\begin{array}{l}\text { Anastomotic } \\
\text { leakage }\end{array}$} & Obstruction & $9(6.2 \%)$ & \multirow[t]{3}{*}{ P Chi-Square Tests $=0.046$} \\
\hline & Hemorrhage & $8(16 \%)$ & \\
\hline & Elective & $20(6.5 \%)$ & \\
\hline \multirow{2}{*}{$\begin{array}{l}\text { Anastomotic } \\
\text { leakage }\end{array}$} & Emergency & $17(8.7 \%)$ & \multirow[t]{2}{*}{ P Fischer's Exact Test $=0.341$} \\
\hline & Elective & $20(6.5 \%)$ & \\
\hline \multirow{2}{*}{$\begin{array}{l}\text { Anastomotic } \\
\text { leakage }\end{array}$} & Yes & Age $=80.33 \pm 8.08$ & \multirow{2}{*}{$\begin{array}{l}\text { P Independent Samples T-Test, } \\
\text { Bootstrap }=0.001\end{array}$} \\
\hline & No & $\mathrm{Age}=68.54 \pm 10.16$ & \\
\hline \multirow{4}{*}{$\begin{array}{l}\text { Anastomotic } \\
\text { leakage }\end{array}$} & Yes & Hemoglobin on admission & \multirow{4}{*}{$\begin{array}{l}\text { P Independent Sample T-Test, } \\
\text { Bootstrap }=0.009\end{array}$} \\
\hline & & $=13.19 \pm 1.56$ & \\
\hline & No & Hemoglobin on admission & \\
\hline & & $=11.70 \pm 3.09$ & \\
\hline \multirow{4}{*}{$\begin{array}{l}\text { Anastomotic } \\
\text { leakage (Yes) }\end{array}$} & TNM Sage I & $0(0 \%)$ & \multirow[t]{4}{*}{ P Chi-Square Tests $=0.001$} \\
\hline & TNM Sage II & $0(0 \%)$ & \\
\hline & TNM Sage III & $24(11 \%)$ & \\
\hline & TNM Sage IV & $13(9.9 \%)$ & \\
\hline
\end{tabular}


Table 2. Correlation between the emergency patients and TNM stage of the disease.

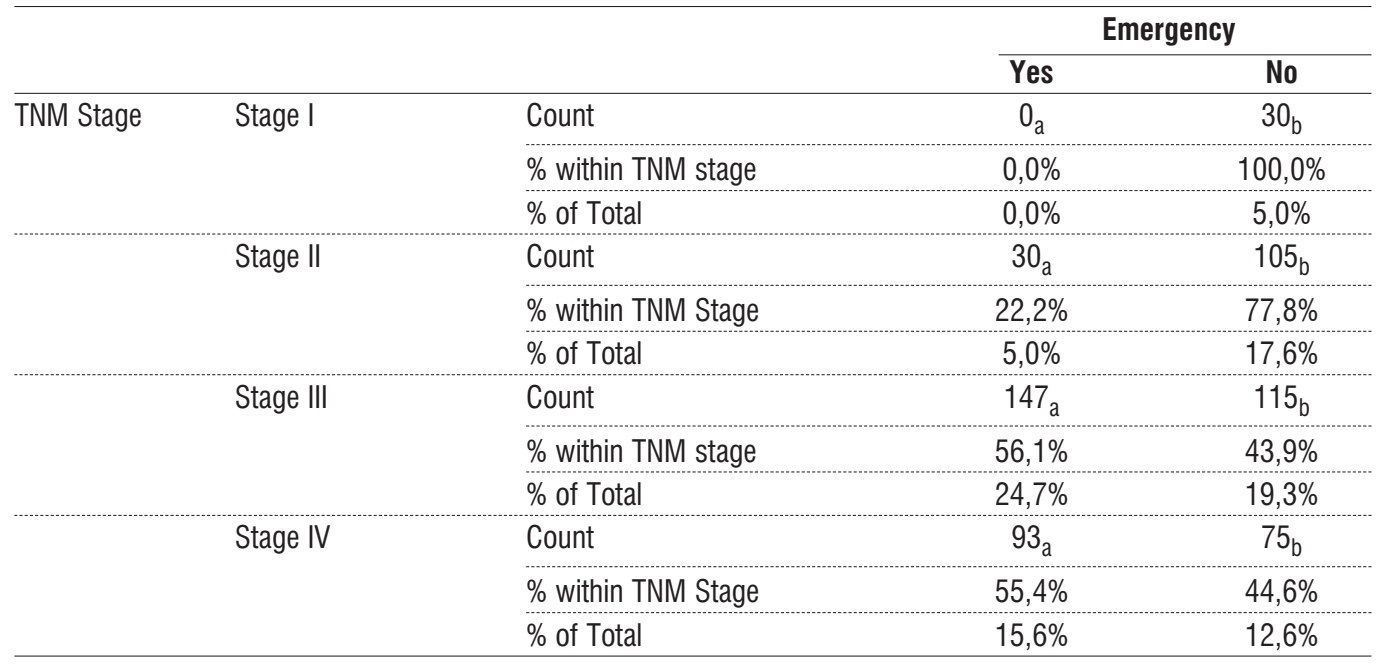

associated with a significantly higher rate of total/subtotal colectomies and Harmann's type resections (see Table 3). The anastomotic leakage rate was similar between obstructive and elective cases $(6.2 \%$ versus $6.5 \%, \mathrm{P}>0.05)$, but was significantly higher for hemorrhagic patients $(16 \%) \quad(\mathrm{P}=0.046)$. The anastomotic leakage rate correlates with the patients' age (80.33 \pm 8.08 versus $68.54 \pm 10.16, \quad \mathrm{P}=0.001)$, lower hemoglobin $(13.19 \pm 1.56$ versus $11.70 \pm 3.09, \mathrm{P}=0.009)$, and advanced disease stage $(\mathrm{P}=0.001)$.We found no association between diabetes mellitus, cardiovascular morbidities, respiratory pre-existing morbidities and anastomotic leakage rate $(\mathrm{P}>0.05)$ (see Table 4). The 30-day complication rate and mortality were significantly higher in emergency patients $(\mathrm{P}<0.05)$ (see Table 5). Emergent surgery was associated with a higher reintervention rate $(\mathrm{P}=0.018)$. The $\mathrm{R} 1 / \mathrm{R} 2$-type resections were more frequent in nonelective patients $(\mathrm{OR}=$ $2.308,95 \%$ CI 2.106 to 2.529$)$. The overall survival was significantly worse for emergency cases, with an odds ratio of 1.702 (95\%

Table 3. Correlation of the emergency status with the surgical procedure

\begin{tabular}{lcccc}
\hline & & \multicolumn{2}{c}{ Emergency } & Total \\
\cline { 3 - 4 } Surgical resection & Yes & No & \\
& & $85_{\mathrm{a}}$ & $165_{\mathrm{b}}$ & 250 \\
& Total hemicolectomy & $34,0 \%$ & $66,0 \%$ & $100,0 \%$ \\
& Hartmann's type & $29 \mathrm{a}$ & $0 \mathrm{~b}$ & 29 \\
& $100,0 \%$ & $0,0 \%$ & $100,0 \%$ \\
\cline { 3 - 5 } & $46_{\mathrm{a}}$ & $5_{\mathrm{b}}$ & 51 \\
& Sigmoidectomy & $90,2 \%$ & $9,8 \%$ & $100,0 \%$ \\
& $110_{\mathrm{a}}$ & $135_{\mathrm{a}}$ & 245 \\
& Resection of the splenic angle & $44,9 \%$ & $55,1 \%$ & $100,0 \%$ \\
& $15 \mathrm{a}$ & $10 \mathrm{a}$ & 25 \\
& $60,0 \%$ & $40,0 \%$ & $100,0 \%$ \\
\hline
\end{tabular}

Each subscript letter denotes a subset of Emergency categories whose column proportions do not differ significantly from each other at the 0,05 level. 
Table 4. Preexisting co-morbidities impact on anastomotic leakage rate

\begin{tabular}{lcc}
\hline Co-morbidity & Odds Ratio & $\begin{array}{c}\text { 95\% Confidence } \\
\text { Interval }\end{array}$ \\
\hline Diabetes mellitus (Yes/No) & 1.397 & $0.554-3.518$ \\
\hline Cardiovascular diseases (Yes/No) & 1.670 & $0.767-3.634$ \\
\hline Respiratory diseases (Yes/No) & 1.459 & $0.477-4.461$ \\
\hline
\end{tabular}

Confidence Interval 1.373 to 2.109) (see Table 6 and Fig. 1). Subgroup analysis of the overall survival according to the patients' gender showed a worse survival in male patients for elective cases $(\mathrm{OR}=0.809,95 \%$ CI 0.712 to 0.919), but nor in emergent surgeries $(\mathrm{OR}=$ $0.907,95 \%$ CI 0.727 to 1.130 ). Patients with perforated tumors presented the worse overall survival (see Table 7 and Fig. 2). After propensity score matching, the emergency surgery was also associated with worse overall survival (see Fig. 3).

\section{Discussions}

The present study revealed significant worse short- and long-term outcomes for patients with complicated left-sided colon cancer.

There is evidence that women have longer adjusted survival compared with men (14), although they present more frequent as emergencies, and at older ages $(\mathrm{HR}=0.91, \mathrm{P}<$ 0.001) (15). In our study, we found a gender

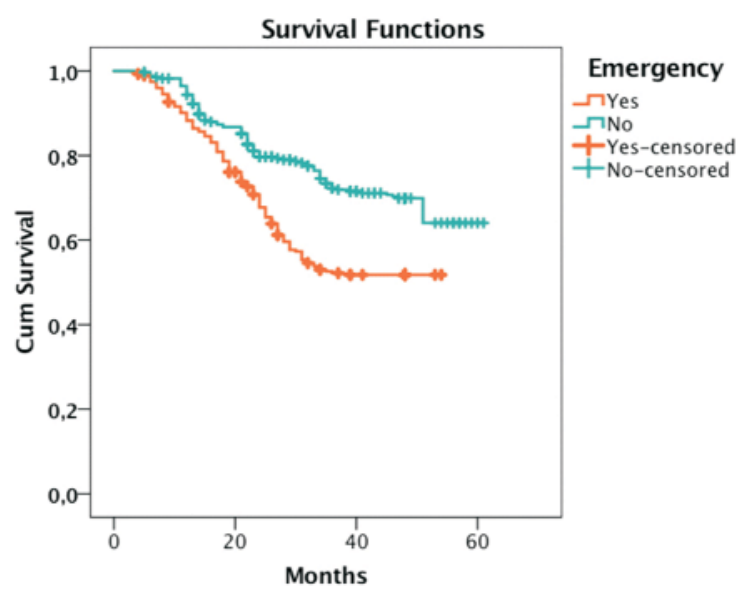

Figure 1. Kaplan-Meyer analysis for Overall Survival of emergency versus elective colon cancer resections (P Long Rank (Mantel-Cox)<0.001).

effect, with better overall survival in women, in elective cases, but not in emergent ones.

Although controversial, the laparoscopic approach may be used for selected cases, with similar 3-year overall survival rate, 3-year recurrence free survival rate, lymph node harvesting and shorter hospital stay (16). In our cohort, including only emergency patients, the emergency laparoscopic approach was used in $3.6 \%$ of patients.

According to Danish Colorectal Cancer Group Database, the postoperative mortality after emergency colonic resections for cancer was $22 \%$, while in patients who develop medical

Table 5. Correlation between postoperative morbidity according to Clavien-Dindo Scale and type of colon cancer complication

\begin{tabular}{|c|c|c|c|c|c|c|c|c|c|}
\hline & & & \multicolumn{6}{|c|}{ Postoperative Complications Clavien Dindo Class } & \multirow[t]{2}{*}{ Total } \\
\hline & & & $\mathrm{I}$ & II & III & IV & V & No & \\
\hline Complication & Hemorrhage & Count & $9_{\mathrm{a}}$ & $4 a$ & $5 \mathrm{~b}$ & $11_{a}$ & $0_{\mathrm{a}}$ & $36_{\mathrm{a}}$ & 55 \\
\hline \multirow[t]{7}{*}{ of the disease } & & $\%$ within Complication of the disease & $16,4 \%$ & $7,3 \%$ & $9,1 \%$ & $1,8 \%$ & $0,0 \%$ & $65,5 \%$ & $100,0 \%$ \\
\hline & Perforation & Count & $0_{a}$ & $4_{b}, c$ & $0_{a}, b, c$ & $1 \mathrm{a}, \mathrm{c}$ & $5 b$ & $5 a$ & 15 \\
\hline & & $\%$ within Complication of the disease & $0,0 \%$ & $26,7 \%$ & $0,0 \%$ & $6,7 \%$ & $33,3 \%$ & $33,3 \%$ & $100,0 \%$ \\
\hline & Obstruction & Count & $32 a$ & $10_{a}$ & $3 a$ & $10_{a}$ & $5 a$ & $145 \mathrm{a}$ & 205 \\
\hline & & $\%$ within Complication of the disease & $15,6 \%$ & $4,9 \%$ & $1,5 \%$ & $4,9 \%$ & $2,4 \%$ & $70,7 \%$ & $100,0 \%$ \\
\hline & Elective & Count & $41_{a}, b$ & $11_{b}$ & $0_{c}$ & $11_{\mathrm{a}, \mathrm{b}}$ & $6 a_{a}, b$ & $271_{\mathrm{a}}$ & 340 \\
\hline & & $\%$ within Complication of the disease & $12,1 \%$ & $3,2 \%$ & $0,0 \%$ & $3,2 \%$ & $1,8 \%$ & $79,7 \%$ & $100,0 \%$ \\
\hline \multirow[t]{2}{*}{ Total } & & Count & 82 & 29 & 8 & 23 & 16 & 457 & 615 \\
\hline & & $\%$ within Complication of the disease & $13,3 \%$ & $4,7 \%$ & $1,3 \%$ & $3,7 \%$ & $2,6 \%$ & $74,3 \%$ & $100,0 \%$ \\
\hline
\end{tabular}

Each subscript letter denotes a subset of Postoperative Complications Clavien Dindo Class categories whose column proportions do not differ significantly from each other at the 0.05 level. 
Table 6. Overall survival of patients with emergency versus elective colon cancer surgery

\begin{tabular}{lccc}
\hline \multicolumn{3}{c}{ Risk Estimate } \\
\hline & Value & $\begin{array}{c}\text { 95\% Confidence } \\
\text { Interval }\end{array}$ \\
\hline & & Lower & Upper \\
\hline $\begin{array}{l}\text { Odds Ratio for Emergency } \\
\text { (Yes } / \text { No) }\end{array}$ &, 432 &, 309 &, 605 \\
\hline For cohort Survival = Yes &, 736 &, 647 &, 836 \\
\hline For cohort Survival $=$ No & 1,702 & 1,373 & 2,109 \\
\hline N of Valid Cases & 615 & & \\
\hline
\end{tabular}

complications was as high as $57.8 \%(7,17)$. The anastomotic leak significantly worsens not only on the early postoperative results but is associated with increased distant recurrence rate $(\mathrm{HR}=1.42$, 95\% CI 1.13 to 1.78 ) and long-term all-cause mortality (HR $=1.20,95 \%$ CI 1.01 to 1.44$)(18)$. These maybe partially explained by canceled of delayed chemotherapy administration (18). In our patients, the emergency surgery was not associated with an increased risk of anastomotic leakage in obstructive lesions, but this was significantly higher in hemorrhagic patients. However, should be noted that in obstructive lesions, the proportion of Hartmann's type resections, and total/subtotal colectomies was significantly higher than in elective patients.

The Dutch Surgical Colorectal Audit showed $5934(19.2 \%)$ out of 30907 patients with nonelective colonic resection managed between 2009 and 2013 (19). The mortality was significantly higher after non-elective procedures (8.5\% versus $3.4 \%, \mathrm{P}<0.001)$. After emergency procedures, the right-sided tumors and anastomotic leakage were prognostic factors for high mortality (19). For elderly patients (more than 80 years) with an American Society of

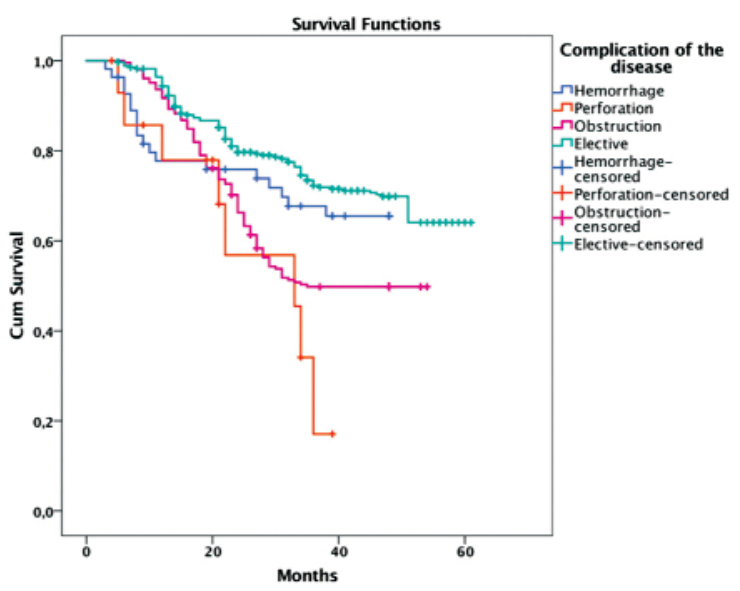

Figure 2. Kaplan-Meyer analysis for Overall Survival of emergency (with subgroups according to the complication type) versus elective colon cancer resections.

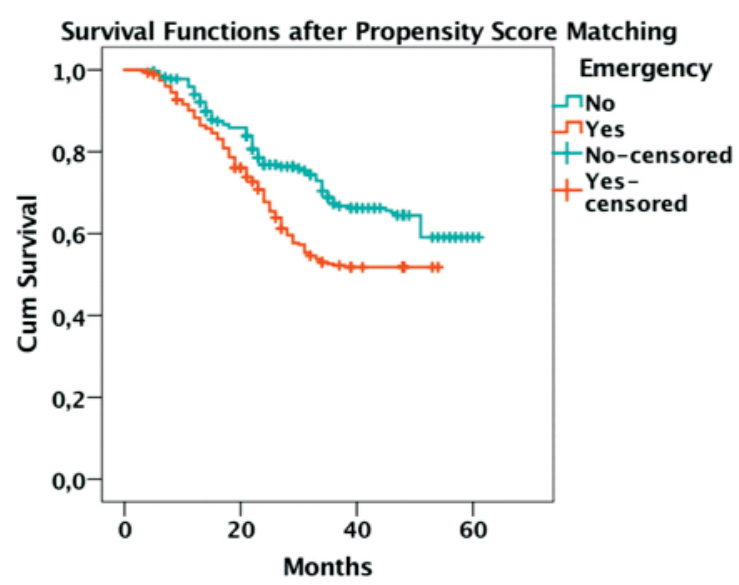

Figure 3. Kaplan-Meyer analysis for Overall Survival of emergency (with subgroups according to the complication type) versus elective colon cancer resections (P Long Rank (Mantel-Cox)=0.001).

Anesthesiology score equal or higher than III and a left hemicolectomy in non-elective setting, the

Table 7. Log rank (Mantel-Cox) pairwise comparison for Overall Survival of emergency (with subgroups according to the complication type) versus elective colon cancer resections.

\begin{tabular}{|c|c|c|c|c|c|c|c|c|c|}
\hline \multicolumn{10}{|c|}{ Pairwise Comparisons } \\
\hline & Complication & Hemorrhage & Perforation & Obstruction & Elective & & & & \\
\hline & of the disease & Chi-Square & Sig. & Chi-Square & Sig. & Chi-Square & Sig. & Chi-Square & Sig. \\
\hline \multirow[t]{4}{*}{ Log Rank (Mantel-Cox) } & Hemorrhage & & & 3,673 & 0,055 & 2,446 & 0,118 & 1,330 & 0,249 \\
\hline & Perforation & 3,673 & 0,055 & & & 1,755 & 0,185 & 12,413 & 0,000 \\
\hline & Obstruction & 2,446 & 0,118 & 1,755 & 0,185 & & & 22,313 & 0,000 \\
\hline & Elective & 1,330 & 0,249 & 12,413 & 0,000 & 22,313 & 0,000 & & \\
\hline
\end{tabular}


postoperative mortality is $41 \%$, significantly higher than $7 \%$ for patients without additional morbidities (20).

An investigation of the 11-year practice of emergency colorectal surgery in the United Kingdom, including 102236 patients, revealed a 30 -day in-hospital mortality of $13.3 \%$ for colorectal cancer and $15.4 \%$ for diverticular disease (21). The 1-year postoperative mortality was $34.7 \%$ and $22.6 \%$, respectively (21). Mamidanna et al. evaluated all patients over 70 years who underwent nonelective colorectal resections in English National Health Service Trust hospitals between 2001 and 2008 (22). 30day mortality was $17 \%, 23.3 \%$, and $31 \%$ for patients aged 70-75, 76-80, and > 80 years old $(\mathrm{P}<0.001)$. The reoperation rate was $6.3 \%$, and the overall 30-day medical complication rate was $33.7 \%$. The 1-year postsurgical mortality was $51.2 \%$ in patients over 80 years old (22). In our study, emergency patients presented a higher postoperative overall morbidity, severe complication, and mortality rate.

Analysis of 473619 surgical procedures from 198 hospitals included in the American College of Surgeons National Surgical Quality Improvement Program, revealed that emergency general surgery procedures are associated with increased overall morbidity $(\mathrm{OR}=1.20, \mathrm{P}<0.05)$, serious morbidity $(\mathrm{OR}=1.26, \mathrm{P}<0.05)$, and mortality $(\mathrm{OR}$ $=1.39, \mathrm{P}<0.05)(1)$. Aquina et al. underlined the public health burden represented by the nonelective colon cancer resections (5). They published the results of 26420 colon cancer patients included in the New York State Cancer registry and Statewide Planning and Research Cooperative System. $26.5 \%$ of patients were operated in emergency conditions, and were associated with increased 30-day mortality $(\mathrm{OR}=3.42,95 \% \mathrm{CI}$ 2.87 to 4.06$)$, stoma creation ( $\mathrm{OR}=4.49,95 \% \mathrm{CI}$ 3.95 to 5.09), discharge to another healthcare facility ( $\mathrm{OR}=2.46,95 \%$ CI 2.26 to 2.68$)$, worse disease specific (hazard ratio $-\mathrm{HR}=1.74,95 \% \mathrm{CI}$ 1.61 to 1.88$)$ and overall survival $(\mathrm{HR}=1.64,95 \%$ CI 1.55 to 1.75) (5). Analysis of the 214174 colec- $^{-}$ tomies, defined as those performed during the first 24 hours from admission, from National Cancer Database revealed that $30 \%$ were performed in emergency conditions. Analysis of 30685 patients from the Surveillance, Epidemiology and End Results database showed a five-year disease specific survival of $86.3 \%$ and $75.4 \%$ of elective and emergency colon cancer resections, respectively (11). However, an important proportion of these differences were explained by more advanced tumor stages and preexisting comorbidities in patients with non-elective resections (11). Although inferior long-term survival is associated with emergency surgery and inappropriate lymphadenectomy, the lymph node harvest seems to be similar between emergent and elective colon resections (23). In our study, we found a higher rate of R1/R2-type resections in emergent cases.

All the outcomes of patients with colon cancer seems to be improved by their management from high volume surgeons $(24,25)$ : the postoperative mortality is lower $(\mathrm{OR}=0.75$, $95 \%$ CI 0.62 to 0.92 ), better 5-year overall survival (OR $=1.14,95 \%$ CI 1.08 to 1.20$)$, and lower anastomotic leakage rate (OR 0.64, 95\% CI 0.40-1.02) (24). Due to technical challenges and high complication rate associated with emergency colectomies, we may assume the necessity of highly experienced surgeons for patients with complicated disease. A comparison of hospital performance in trauma versus emergency and elective general surgery revealed a significantly better processes organization and quality of care for trauma patients than for general emergency procedures (26).

The results of the present study should be considered in light of several limitations, especially due to its retrospective nature. First, a major limitation of the current research is the heterogeneity of patients defined as emergency cases. Second, there was a relatively low number of perforated tumors, which were associated with a significantly lower short- and long-term outcomes than the other two complications. However, using propensity score matching we diminished the impact of heterogeneity between the groups, but these were not repealed.

\section{Conclusions}

The present study revealed significant worse short- and long-term outcomes for patients with nonelective left-sided colon cancer resec- 
tions. Correlating the ominous prognosis with the high incidence of the complicated disease, we may emphasize the impact on de complicated colon cancer on the general population.

\section{Conflict of Interests}

The authors declare no conflict of interests.

\section{References}

1. Ingraham $\mathrm{AM}$, Cohen $\mathrm{ME}$, Raval MV, Ko CY, Nathens $\mathrm{AB}$. Comparison of hospital performance in emergency versus elective general surgery operations at 198 hospitals. Journal of the American College of Surgeons. 2011;212(1):20-8.e1.

2. Ricciardi R, Roberts PL, Read TE, Baxter NN, Marcello PW, Schoetz DJ. Mortality rate after nonelective hospital admission. Archives of surgery (Chicago, III : 1960). 2011;146(5):545-51.

3. Weixler B, Warschkow R, Ramser M, Droeser R, von Holzen U, Oertli $\mathrm{D}$, et al. Urgent surgery after emergency presentation for colorectal cancer has no impact on overall and disease-free survival: a propensity score analysis. BMC cancer. 2016;16:208.

4. Xu Z, Becerra AZ, Aquina CT, Hensley BJ, Justiniano CF, Boodry C, et al. Emergent Colectomy Is Independently Associated with Decreased Long-Term Overall Survival in Colon Cancer Patients. Journal of gastrointestinal surgery : official journal of the Society for Surgery of the Alimentary Tract. 2017;21(3):543-53.

5. Aquina CT, Becerra AZ, Xu Z, Boscoe FP, Schymura MJ, Noyes K, et al. Nonelective colon cancer resection: A continued public health concern. Surgery. 2017;161(6):1609-18.

6. Oliphant R, Mansouri D, Nicholson GA, McMillan DC, Horgan PG, Morrison DS. Emergency presentation of node-negative colorectal cancer treated with curative surgery is associated with poorer short and longer-term survival. International journal of colorectal disease. 2014;29(5):591-8.

7. Iversen LH. Aspects of survival from colorectal cancer in Denmark. Danish medical journal. 2012;59(4):B4428.

8. Byrne BE, Mamidanna R, Vincent CA, Faiz OD. Outlier identification in colorectal surgery should separate elective and nonelective service components. Diseases of the colon and rectum. 2014; 57(9):1098-104.

9. Obirieze AC, Kisat M, Hicks CW, Oyetunji TA, Schneider EB, Gaskin DJ, et al. State-by-state variation in emergency versus elective colon resections: room for improvement. The journal of trauma and acute care surgery. 2013;74(5):1286-91.

10. Haider AH, Obirieze A, Velopulos CG, Richard P, Latif A, Scott VK, et al. Incremental Cost of Emergency Versus Elective Surgery. Annals of surgery. 2015;262(2):260-6.

11. Paulson EC, Mahmoud NN, Wirtalla C, Armstrong K. Acuity and survival in colon cancer surgery. Diseases of the colon and rectum. 2010;53(4):385-92.

12. Askari A, Nachiappan S, Currie A, Bottle A, Abercrombie J,
Athanasiou T, et al. Who requires emergency surgery for colorectal cancer and can national screening programmes reduce this need? International journal of surgery (London, England). 2017;42:60-8.

13. Zhou Y, Abel GA, Hamilton W, Pritchard-Jones K, Gross CP, Walter FM, et al. Diagnosis of cancer as an emergency: a critical review of current evidence. Nature reviews Clinical oncology. 2017;14(1):4556.

14. Quirt JS, Nanji S, Wei X, Flemming JA, Booth CM. Is there a sex effect in colon cancer? Disease characteristics, management, and outcomes in routine clinical practice. Current oncology (Toronto, Ont). 2017;24(1):e15-e23.

15. Paulson EC, Wirtalla C, Armstrong K, Mahmoud NN. Gender influences treatment and survival in colorectal cancer surgery. Diseases of the colon and rectum. 2009;52(12):1982-91.

16. Odermatt M, Miskovic D, Siddiqi N, Khan J, Parvaiz A. Short- and long-term outcomes after laparoscopic versus open emergency resection for colon cancer: an observational propensity scorematched study. World journal of surgery. 2013;37(10):2458-67.

17. Ingeholm P, Gögenur I, Iversen LH. Danish Colorectal Cancer Group Database. Clinical Epidemiology. 2016;8:465-8.

18. Krarup PM, Nordholm-Carstensen A, Jorgensen LN, Harling $\mathrm{H}$. Anastomotic leak increases distant recurrence and long-term mortality after curative resection for colonic cancer: a nationwide cohort study. Annals of surgery. 2014;259(5):930-8.

19. Bakker IS, Snijders HS, Grossmann I, Karsten TM, Havenga K, Wiggers T. High mortality rates after nonelective colon cancer resection: results of a national audit. Colorectal disease : the official journal of the Association of Coloproctology of Great Britain and Ireland. 2016;18(6):612-21.

20. Kolfschoten NE, Wouters MW, Gooiker GA, Eddes EH, Kievit J, Tollenaar RA, et al. Nonelective colon cancer resections in elderly patients: results from the dutch surgical colorectal audit. Dig Surg. 2012;29(5):412-9.

21. Faiz O, Warusavitarne J, Bottle A, Tekkis PP, Clark SK, Darzi AW, et al. Nonelective excisional colorectal surgery in English National Health Service Trusts: a study of outcomes from Hospital Episode Statistics Data between 1996 and 2007. Journal of the American College of Surgeons. 2010;210(4):390-401.

22. Mamidanna R, Eid-Arimoku L, Almoudaris AM, Burns EM, Bottle A, Aylin $P$, et al. Poor 1-year survival in elderly patients undergoing nonelective colorectal resection. Diseases of the colon and rectum. 2012;55(7):788-96

23. Lewis A, Akopian G, Carillo S, Kaufman HS. Lymph node harvest in emergent versus elective colon resections. The American surgeon. 2012:78(10):1049-53.

24. Morche J, Mathes T, Pieper D. Relationship between surgeon volume and outcomes: a systematic review of systematic reviews. Systematic Reviews. 2016;5.

25. Archampong D, Borowski D, Wille-Jorgensen P, Iversen LH. Workload and surgeon's specialty for outcome after colorectal cancer surgery. The Cochrane database of systematic reviews. 2012(3):Cd005391.

26. Ingraham AM, Haas B, Cohen ME, Ko CY, Nathens AB. Comparison of hospital performance in trauma vs emergency and elective general surgery: implications for acute care surgery quality improvement. Archives of surgery (Chicago, III : 1960). 2012;147(7):591-8. 